Egyptian Journal of Aquatic Biology \& Fisheries

Zoology Department, Faculty of Science,

Ain Shams University, Cairo, Egypt.

ISSN $1110-6131$

Vol. 25(2): 935 - 946 (2021)

www.ejabf.journals.ekb.eg

\title{
The 100 Most Cited Articles in Zebrafish: a Bibliometric Perspective
}

\section{Salmi Ab. Aziz ${ }^{1}$, Mohd H. Mohd Nasir ${ }^{2,3}$, Ab. Rashid Jusoh ${ }^{1}$, Asma H.Ahmad ${ }^{4}$, Zahiruddin Othman ${ }^{4}$, Aidi Ahmi ${ }^{5}$, Rahimah Zakaria ${ }^{4 *}$}

${ }^{1}$ School of Health Sciences, Health Campus, Universiti Sains Malaysia 16150 Kota Bharu, Kelantan, Malaysia

${ }^{2}$ Central Research and Animal Facility (CREAM), Kulliyyah of Science, International Islamic University Malaysia, 25200 Kuantan, Pahang, Malaysia

${ }^{3}$ Department of Biotechnology, Kulliyyah of Science, International Islamic University Malaysia, 25200

Kuantan, Pahang, Malaysia

${ }^{4}$ School of Medical Sciences, Health Campus, Universiti Sains Malaysia, 16150 Kota Bharu, Malaysia

${ }^{5}$ Tunku Puteri Intan Safinaz School of Accountancy, Universiti Utara Malaysia 06010 UUM Sintok, Kedah, Malaysia

*Corresponding Author: rahimah@usm.my

\begin{tabular}{|c|c|}
\hline ARTICLE INFO & ABSTRACT \\
\hline Article History: & The 100 most cited articles in zebrafish were published between 1990 and \\
\hline Received: March 9, 2021 & 2015, with $70 \%$ published after 2000 . The most cited article received 7379 \\
\hline Accepted: April 23, 2021 & citations, while the least received only 405 . The 100 most cited articles were \\
\hline April 30, 2021 & $\begin{array}{l}\text { published in } 39 \text { different journals with Development having the highest } \\
\text { citations }(n=11,966) \text { as well as the highest total publications }(n=21) \text {. }\end{array}$ \\
\hline $\begin{array}{l}\text { Keywords: } \\
\text { Zebrafish, } \\
\text { Danio rerio, } \\
\text { Scopus, } \\
\text { Harzing Publish, } \\
\text { Perish, } \\
\text { VOSviewer }\end{array}$ & $\begin{array}{l}\text { Eighteen authors listed four or more articles, while the USA was found to be } \\
\text { the most prolific country, producing } 81 \text { articles, and having the most } \\
\text { affiliated institutions and the top research funders. The most frequent } \\
\text { keywords were "zebrafish" followed by "Danio rerio", "blastula", } \\
\text { "cleavage", "embryogenesis", "mesoderm", "notochord", and } \\
\text { "somitogenesis". This bibliometric data render a historical perspective on } \\
\text { the advancement of zebrafish research, and facilitate mapping potential } \\
\text { authors, institutions and countries for future collaborations as well as } \\
\text { important key topics for future research. }\end{array}$ \\
\hline
\end{tabular}

\section{INTRODUCTION}

Zebrafish (Danio rerio) is a teleost fish in the Cyprinidae family under Actinopterygii (ray-finned fishes) class. It is a small tropical freshwater fish that originates in Northern India's Ganges River and its tributaries (Tavares et al., 2013). The zebrafish is one of the most popular models in various research fields such as developmental biology, drug discovery, cancer, molecular genetics, toxicology, human and animal health research, as well as aquaculture research (Hason \& Bartůněk, 2019; Khan \& Alhewairini, 2019; Teame et al., 2019; Hayati et al., 2020; Jørgensen, 2020). The main advantages of using zebrafish are summarized as follow: early-life optical transparency, a short generation period, continuous and numerous egg production, rapid 
development, a wide spectrum of mutant/transgenic lines, the ease with which genetic manipulations can be conducted and comparatively low cost of facilities (Jørgensen, 2020).

Human and zebrafish have many physiological and genetic similarities, including brain, muscles, gastrointestinal tract, vessels, and innate immune system (Lieschke et al., 2001; Weinstein, 2002; Guyon et al., 2007; Gore et al., 2012; Kalueff et al., 2014; Kanungo et al., 2014; Zhao et al., 2016). The majority of tissues and organs in both humans and zebrafish are identical except for the lungs, prostate and breast (Khan \& Alhewairini, 2019). The first human illness detected using zebrafish was a low haemoglobin production resulting from a mutation in the gene coding for ALAS2 (Chitramuthu, 2013). Numerous other mutations in haematological disorders (Brownlie et al., 1998; Berman et al., 2012), cardiovascular diseases (Sehnert et al., 2002), cancers (Patton et al., 2005; Liu and Leach, 2011), muscle disease (Lin, 2012), neurological disorders (Gama Sosa et al., 2012) including Parkinson's disease (Sarath et al., 2016), anxiety, and posttraumatic stress disorder (Chakravarty et al., 2013) have been found to display similar phenotype to human disease. In terms of aquaculture research, various infections including: tuberculosis, streptococcal and salmonella are studied using zebrafish disease models (Van der Sar et al., 2004).

The zebrafish is emerging as an increasingly successful model for various translational researches, and the number of worldwide publications is rapidly growing over time. The bibliometric analysis enables the researcher to study the growth and trend of a particular research field and helps in identifying prominent authors, institutes, countries etc. Up till now, only two bibliometric studies are detected on zebrafish research output. The first study, "Mapping of zebrafish research: a global outlook", was published in 2013 by Kinth et al. (2013). The second recently published article which was entitled "Zebrafish as an emerging model system in the Global South: two decades of research in Brazil" by Triguero et al. (2020). The first article used the Web of Science database for the period from 1945 to December 2012 to map significant publication patterns and development in zebrafish research, and to evaluate the research performance from multiple perspectives. The second article also used the Web of Science database to evaluate the use of zebra fish as a model system for research in the Global South, with Brazil as a case study. They reported rapid growth of Brazilian scientific production using the zebrafish model, especially in three main areas such as neuroscience and behavior, pharmacology and toxicology, and environment/ecology research. The article also showed that research related to toxicological approaches are widespread in Global South countries such as Brazil. The present study, however, used the Scopus database to identify the 100 most cited articles in worldwide research related to zebrafish using a bibliometric approach.

\section{MATERIAL AND METHODS}

In the present study, a literature search was done in the Scopus database as of November 2020. The terms "zebrafish" OR "zebra fish" OR "Danio rerio" in the article title were used to search relevant articles related to zebrafish research. The retrieved documents were structured in decreasing order of the number of citation counts 
and the 100 most cited articles were recorded. There were no restrictions in terms of document type, source type, language and publication date or status.

Harzing Publish or Perish (www.harzing.com) was used to calculate the citation metric. Moreover, Microsoft Excel 2016 was to evaluate characteristics of citation (authors, title, year of publication, journal, and citations); and VOSviewer software version 1.6.15 (Center for Science and Technology Studies of Leiden University, Netherlands) was utilized to create and visualize the bibliometric network.

\section{RESULTS}

\section{Type of document, number of citations and citation density}

Of the 100 most cited articles, 89 were original articles, 9 were review papers, and 2 were letters. All the articles were written in English. The citation metric of the 100 most cited articles is shown in Table (1). The articles were published between 1990 and 2015, with 70\% published after 1999 (Figure 1). The articles received 72,777 total citations, with h-index and g-index of 100 each. The years 2005 and 2008 recorded the highest number of publications out of the 100 most cited articles ( $n=9$ and 10, respectively).

Table 1: Citation Metric.

$\begin{array}{ll}\text { Publication years } & 1990-2015 \\ \text { Citations } & 72777 \\ \text { Cites/year } & 2347.65 \\ \text { Cites/paper } & 727.77 \\ \text { Authors/paper } & 5.83 \\ \text { h-index } & 100 \\ \text { g-index } & 100\end{array}$

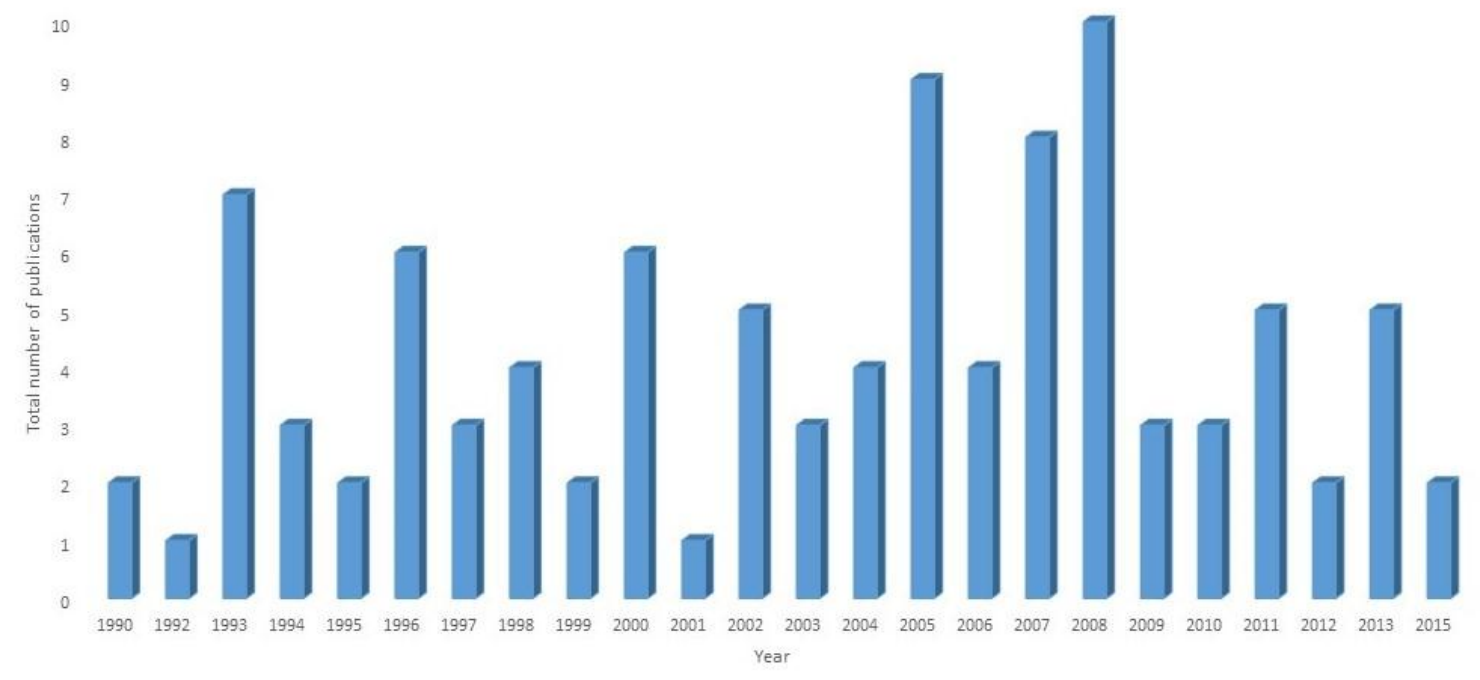

Figure 1: Distribution of 100 most cited articles. 
Each of the top 15 articles received over 1,000 citations. The article of Kimmel et al. (1995) entitled: "Stages of embryonic development of the zebrafish" in the Developmental Dynamics journal received a total of 7,379 citations which was ranked first. Nasevicius and Ekker (2000) article, "Effective targeted gene knockdown in zebrafish", in the Nature Genetics journal was ranked second and received 1,985 citations. Articles by Howe $\boldsymbol{e t}$ al. (2013) and Hwang $\boldsymbol{e t}$ al. (2013) were cited 1711 and 1688 times, respectively. The articles were then ranked in order of their citation density (the total number of citation divided by the number of years in which the article was published). The article with the highest citation density (295.16) was of Kimmel $\boldsymbol{e t}$ al. (1995), whilst the lowest citation (14.23) was of Trevarrow et al. (1990).

\section{Journals characteristics}

A total of 23936 documents on zebrafish research appeared in 160 journals. Journals of the 100 most cited articles are listed in Table (2) in a descending order based on the total number of publications. The articles appeared in 39 separate journals. Development published the largest number of articles $(n=21)$, followed by Science $(\mathrm{n}=10)$, Nature $(n=8)$, and Cell $(n=6)$. Those four journals were responsible for $45 \%$ of the most cited articles in zebrafish research. Twenty three out of 39 journals $(58.8 \%)$ published only one article each in the 100 most cited article list. SCImago Journal Rank (SJR) in Scopus provides an option to the impact factor (IF) or average citations per document over two years, abbreviated as "Cites per Doc. (2y)". The SJR of the journals ranged between 0.769 and 24.698 (mean of 7.018). The journal with the highest SJR (28.619) was Nature Reviews Genetics, which contributed two articles.

Table 2: The journals in which the 100 most cited articles were published

\begin{tabular}{lcclccc}
\hline Journal Title & TP & TC & Publisher & $\begin{array}{c}\text { Cite } \\
\text { Score }\end{array}$ & $\begin{array}{c}\text { SJR } \\
\mathbf{2 0 1 9}\end{array}$ & $\begin{array}{c}\text { SNIP } \\
\text { 2019 }\end{array}$ \\
\hline Development & 21 & 11966 & $\begin{array}{l}\text { The Company of } \\
\text { Biologists Ltd. }\end{array}$ & 8.8 & 3.658 & 1.430 \\
Science & 10 & 9043 & $\begin{array}{l}\text { American Association for } \\
\text { the Advancement of }\end{array}$ & 45.3 & 13.110 & 7.521 \\
& & & & & \\
Science & & & \\
Nature & 8 & 7016 & Springer nature & 51.00 & 14.047 & 8.820 \\
Cell & 6 & 3667 & Elsevier & 58.7 & 24.698 & 7.114 \\
Nature Biotechnology & 5 & 3870 & Springer nature & 31.5 & 12.565 & 5.715 \\
Proceedings of The & 5 & 2611 & National Academy of & 15.7 & 5.165 & 2.689 \\
National Academy of & & & Sciences & & & \\
Sciences of The United & & & & & & \\
States of America & & & & & & \\
Current Biology & 3 & 1761 & Elsevier & 13.8 & 3.958 & 2.318 \\
Nature Genetics & 3 & 3064 & Springer Nature & 19.795 & 6.001 \\
Blood & 2 & 987 & American Society of & 18.6 & 5.416 & 3.215 \\
& & & Hematology & 5.9 & 1.813 & 0.920 \\
Developmental Biology & 2 & 1895 & Elsevier & 15.1 & 5.220 & 2.193 \\
Developmental Cell & 2 & 1003 & Elsevier & 16.8 & 9.245 & 2.534 \\
\hline Genome Research & 5 & 992 & Cold Spring Harbor & &
\end{tabular}




\begin{tabular}{|c|c|c|c|c|c|c|}
\hline & & & Laboratory Press & & & \\
\hline Journal of Neuroscience & 2 & 938 & Society for Neuroscience & 10.5 & 3.701 & 1.528 \\
\hline $\begin{array}{l}\text { Nature Reviews Drug } \\
\text { Discovery }\end{array}$ & 2 & 1369 & Springer Nature & 35.5 & 7.018 & 9.489 \\
\hline $\begin{array}{l}\text { Nature Reviews } \\
\text { Genetics }\end{array}$ & 2 & 1801 & Springer Nature & 73.5 & 28.619 & 9.126 \\
\hline Neuron & 2 & 878 & Elsevier & 24.9 & 9.527 & 3.351 \\
\hline ACS Nano & 1 & 608 & $\begin{array}{l}\text { American Chemical } \\
\text { Society }\end{array}$ & 23.5 & 6.131 & 2.522 \\
\hline $\begin{array}{l}\text { Acta Biochimica et } \\
\text { Biophysica Sinica }\end{array}$ & 1 & 415 & Oxford University Press & 3.2 & 0.672 & 0.500 \\
\hline $\begin{array}{l}\text { ALTEX : Alternativen } \\
\text { zu Tierexperimenten }\end{array}$ & 1 & 425 & Springer Nature & 8.4 & 1.270 & 1.529 \\
\hline $\begin{array}{l}\text { Behavioral Brain } \\
\text { Research }\end{array}$ & 1 & 661 & Elsevier & 5.3 & 1.179 & 0.901 \\
\hline Biological Reviews & 1 & 553 & Wiley-Blackwell & 19.3 & 4.974 & 3.939 \\
\hline Cell Host and Microbe & 1 & 421 & Elsevier & 27.6 & 7.168 & 3.022 \\
\hline Cell Research & 1 & 497 & Springer Nature & 19.8 & 6.141 & 2.276 \\
\hline Cell Stem Cell & 1 & 672 & Elsevier & 35.7 & 9.340 & 3.906 \\
\hline $\begin{array}{l}\text { Current Opinion in } \\
\text { Genetics and } \\
\text { Development }\end{array}$ & 1 & 440 & Elsevier & 10.0 & 3.809 & 1.244 \\
\hline $\begin{array}{l}\text { Developmental } \\
\text { Dynamics }\end{array}$ & 1 & 7379 & Wiley-Blackwell & 5.0 & 1.559 & 0.924 \\
\hline $\begin{array}{l}\text { Environmental Science } \\
\text { and Technology }\end{array}$ & 1 & 438 & $\begin{array}{l}\text { American Chemical } \\
\text { Society }\end{array}$ & 12.6 & 2.704 & 2.060 \\
\hline Immunity & 1 & 408 & Elsevier & 37.4 & 11.977 & 4.273 \\
\hline ISME Journal & 1 & 490 & Springer Nature & 17.3 & 5.073 & 2.384 \\
\hline Journal of Morphology & 1 & 448 & Wiley-Blackwell & 2.7 & 0.681 & 0.800 \\
\hline Nanotechnology & 1 & 669 & $\begin{array}{l}\text { Institute of Physics } \\
\text { Publishing }\end{array}$ & 6.1 & 1.026 & 0.868 \\
\hline Nature Cell Biology & 1 & 505 & Springer Nature & 25.3 & 9.916 & 3.005 \\
\hline Nature Immunology & 1 & 498 & Springer Nature & 29.0 & 9.283 & 3.703 \\
\hline Nature Protocols & 1 & 1438 & Springer Nature & 20.4 & 7.649 & 3.026 \\
\hline Nucleic Acids Research & 1 & 624 & Oxford University Press & 21.1 & 8.907 & 3.545 \\
\hline PLoS ONE & 1 & 608 & Public Library of Science & 5.2 & 1.023 & 1.205 \\
\hline Small & 1 & 440 & Wiley-Blackwell & 15.7 & 3.717 & 1.695 \\
\hline Toxicological Sciences & 1 & 864 & Oxford University Press & 6.2 & 1.175 & 1.037 \\
\hline Zebrafish & 1 & 415 & Mary Ann Liebert & 3.5 & 0.769 & 0.591 \\
\hline
\end{tabular}

Note: $\mathrm{TP}=$ total number of publications; $\mathrm{TC}=$ total citations

\section{Authors}

A total of 160 researchers contributed to the 100 most cited articles. Zon, L. I. authored nine articles followed by Schier A.F. (8 articles), Kimmel C.B., NüssleinVolhard C and Stainier DYR (6 articles each). Fifty-four articles had 1-5 authors in collaboration, while thirty articles had 6 to 12 authors in collaboration and the remaining sixteen articles had more than 12 authors in collaboration. Figure (2) shows a collaboration network that was created for the authors who contributed at least 4 or more articles of the 100 most cited articles. In the collaborative network, only 17 out of 160 most successful authors were linked together. The number of articles published by each 
author is represented by the node size, while the number of publications of two researchers has co-authored, and is represented by the joining lines.

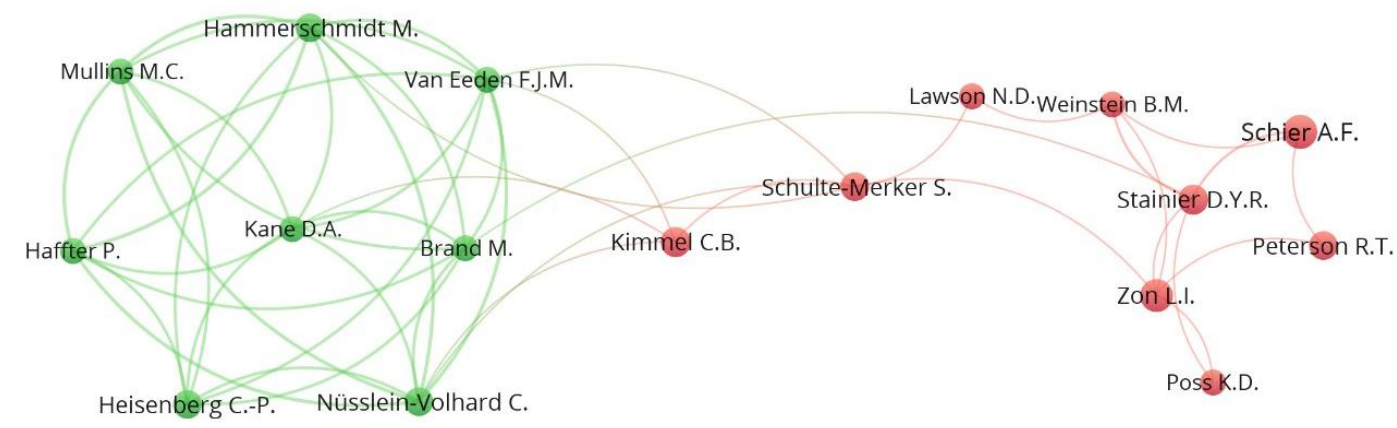

\section{\& Vosviewer}

Figure 2: Co-author contribution with four or more articles with their network in the top 100 most cited articles. Seventeen authors were connected while one author was not connected to each other

\section{Countries of origin, institutions and funding bodies}

The 100 most cited articles on zebrafish are originated from 23 different countries. The most prolific country was the United States with 81 articles, followed by Germany (n $=20)$, the United Kingdom $(n=13)$, the Netherlands $(n=8)$, France $(n=5)$, Japan $(n=$ 5), Canada $(n=3)$, China $(n=3)$, Denmark $(n=3)$, Spain $(n=3)$, Australia $(n=2)$, South Korea $(n=2)$, and the rest of the countries. Figure (3) shows a collaboration network of the countries that was created with a threshold of 2 or more collaborations. The number of international collaboration was the largest in both the United States and Germany.

The institution with the highest number of articles was led by the University of Oregon in the USA $(n=17)$. This was followed by the Howard Hughes Medical Institute in the USA $(n=13)$, and ten articles each from Harvard Medical School in the USA, Max Planck Institute for Developmental Biology in Germany, Massachusetts General Hospital in the USA, and Children's Hospital, Boston in the USA.

The top organizations in the USA that funded zebrafish research were the National Institutes of Health $(n=21)$, Eunice Kennedy Shriver National Institute of Child Health and Human Development $(n=12)$, National Institute of General Medical Sciences $(n=$ 8), National Heart, Lung, and Blood Institute $(n=6)$, March of Dimes Foundation and National Center for Research Resources ( $n=5$ each). 


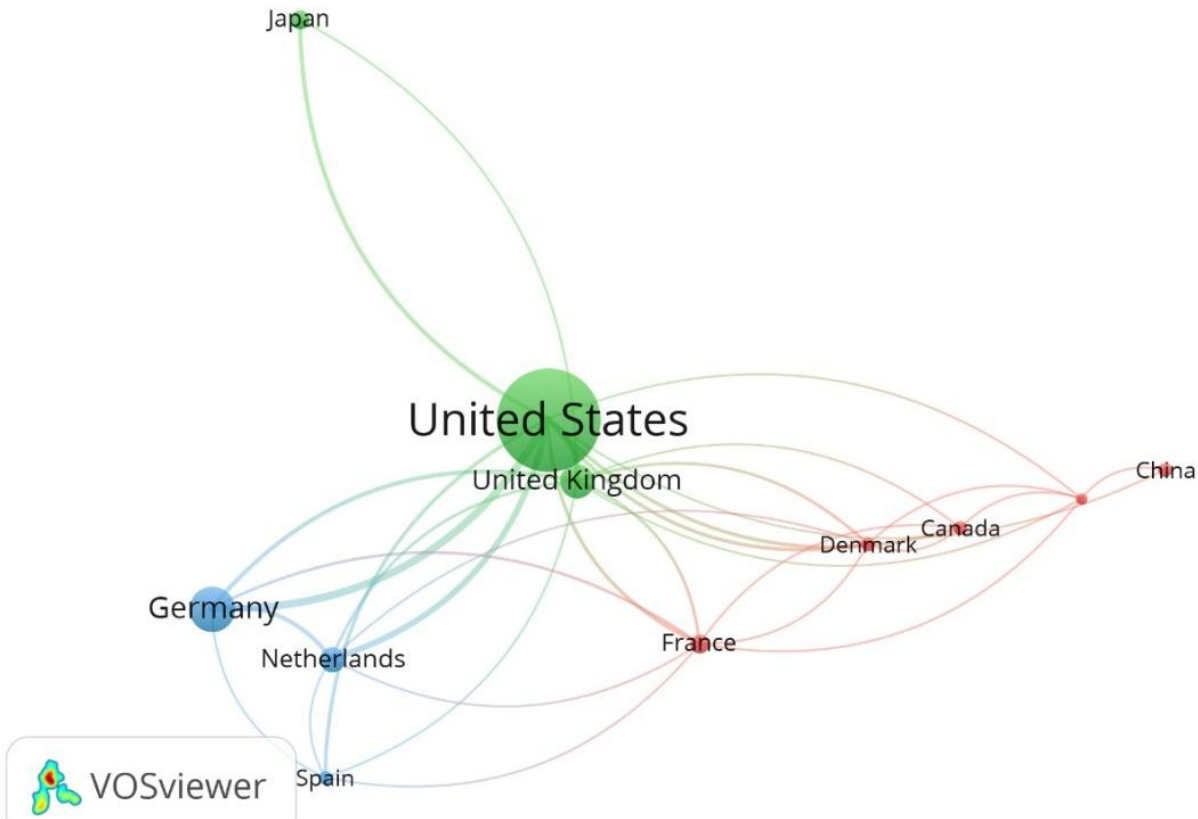

Figure 3: Visualization map of country co-authorship (international collaboration) for publications related to zebrafish

\section{Keywords of the top-cited studies}

A total of 188 author keywords were identified, with 165 of them appearing only once. Figure (4) shows the network analysis of keyword co-occurrence. "Zebrafish" was the largest node, with 23 occurrences, followed by "Danio rerio" (5 occurrences), "blastula", "cleavage", "embryogenesis", "mesoderm", "notochord", and "somitogenesis" (each with 3 occurrences ).

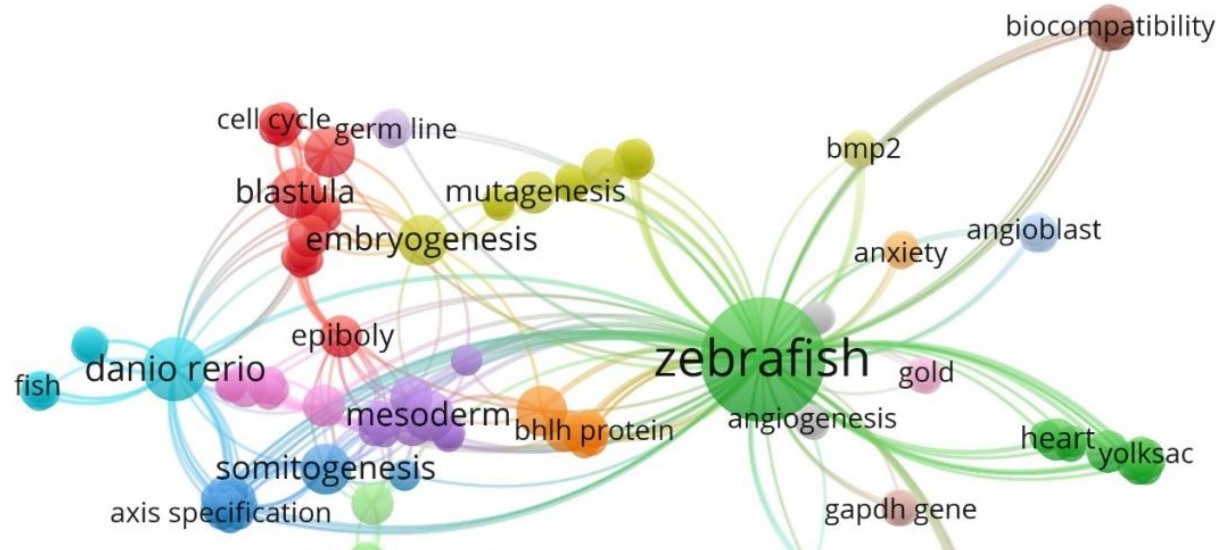

cranial neural crest

blood vessels

\section{VOSviewer}

$$
\text { locomotion }
$$

Figure 4: Keyword co-occurrence network of the 100 top-cited articles 


\section{DISCUSSION}

One of the techniques for determining the most influential articles in a specific field is to use citation analysis. As a mark of distinction for any article, the total citation is acknowledged. An article that has earned 100 or more citations is categorized as a classic paper (Garfield, 1996). In this study, a total of 1626 articles were cited more than 100 times, while 15 articles were cited more than 1000 times. All the 100 most cited articles on zebrafish had more than 400 citations.

As Kinth et al. (2013) previously stated there has been a growing pattern of publication since the 1990s. The oldest and latest publication was respectively dated from 1990 and 2015. Articles of the last five years were included in the present study, and this could be due to several reasons. Older articles typically had plenty of time to reach a global audience and were therefore more likely to be cited than those that were recently published, irrespective of their scientific merit. Consequently, although highly significant, the recent publications would not be reflected in citation analysis. Moreover, landmark trials received less citation because their findings were widely acknowledged that their sources or contributors were frequently forgotten over time. This is referred to as the effect of 'obliteration by incorporation' (Gupta et al., 2020).

To correct the time bias, citation density was calculated, which is the total number of citations divided by the number of years after the publication of each article. The article of Kimmel et al. (1995) entitled "Stages of embryonic development of the zebrafish" published in Developmental Dynamics, received the largest number of citations (7379) as well as the highest citation density (295.16). The second top-cited article, "Effective targeted gene 'knockdown' in zebrafish" (Nasevicius \& Ekker, 2000), moved down to the sixth rank based on citation density, while "The zebrafish reference genome sequence and its relationship to the human genome" (Howe et al., 2013) and "Efficient genome editing in zebrafish using a CRISPR-Cas system" (Hwang et al., 2013) were ranked third and fourth based on total citation, but they were ranked second and third based on citation density.

The 100 most cited articles were published in 39 journals, and Development contributed to the highest number of articles $(n=21)$, followed by Science $(\mathrm{n}=10)$, Nature $(\mathrm{n}=8)$, and Cell $(\mathrm{n}=6)$. Those four journals are responsible for $45 \%$ of the most cited articles in zebrafish research. Development that focused on developmental aspects was also among the top 3 journals reported by Kinth et al. (2013) in their bibliometric analysis published in 2013. Other journals such as Science and Nature are multidisciplinary journal, and Cell is a journal which covers subjects like biochemistry, genetics and molecular biology. These may suggest the shift of focus of subject areas in research related to zebrafish.

Regarding publications by specific authors, Zon LI from the Harvard Medical School, Boston, United States ranked first with nine articles in the list as the first author. This was followed by Schier AF from Harvard University, Cambridge, United States (8 articles), Kimmel CB Form Max Planck Institute for Developmental Biology, USA, and NüssleinVolhard C and Stainier DYR, both from Max Planck Institute, Germany (6 articles each). Those authors (except for Nüsslein-Volhard C) were earlier reported to be the 25 most prominent authors by Kinth et al. (2013). More than half of the most cited articles had 15 contributing authors, while thirty articles had 6 to 12 contributing authors and the 
remaining sixteen articles had more than 12 contributing authors. Other authors noted a similar trend in their bibliometric analyses (Gondivkar et al., 2018; Ahmi et al., 2020; Patil et al., 2020).

In this study, academic institutions in the United States contributed more than $80 \%$ of the articles. This is in agreement with bibliometric studies in other disciplines (Patil $\boldsymbol{e t}$ al., 2020). The current analysis of the co-authorship network showed that most authors who collaborated with authors affiliated either to the same organization or country. Significant collaboration amongst researchers was from the USA, Germany, UK and Netherlands. The top affiliated institutions and the top research funders were mostly from the USA.

The analysis of keywords was conducted to acquire information on patterns of zebrafish research. About 23 out of 188 keywords were identified to appear more than once, and the most frequent was "zebrafish". This was followed by "Danio rerio", "blastula", "cleavage", "embryogenesis", "mesoderm", "notochord", and "somitogenesis". Both "zebrafish" and "Danio rerio" were earlier listed as the most frequent keywords (Kinth et al., 2013; Trigueiro et al., 2020). Other top keywords were related to the development, and it is expected that the most frequent keywords will evolve with time as already observed in the top journals.

\section{CONCLUSIONS}

This is the first article to report the 100 most cited articles in zebrafish research using a bibliometric approach. The list of journals in which the 100 most cited articles were published will guide and benefit future academic pursuits in zebrafish research. This study also maps potential authors, institutions and countries for future collaborations as well as important key topics for future research.

\section{FUNDING}

The authors would like to acknowledge a short-term research grant of Universiti Sains Malaysia (304/ PPSK/6315339) and a Fundamental Research Grant Scheme of Ministry of Higher Education (FRGS/1/2020/SKK0/USM/03/8) for the financial support.

\section{REFERENCES}

Ahmi, A.; Tapa, A. and Hamzah, A. H. (2020). Mapping of financial technology (FinTech) research: A bibliometric analysis. In. J. Adv. Sci. Technol., 29(8): 379392.

Berman, J.; Payne, E. and Hall, C. (2012). The zebrafish as a tool to study hematopoiesis, human blood diseases, and immune function. Adv. Hematol., 2: Article ID 425345. https://doi. org/10.1155/2012/425345

Brownlie, A.; Donovan, A.; Pratt, S. J.; Paw, B. H.; Oates, A. C.; Brugnara, C.; Witkowska, H. E.; Sassa, S. and Zon, L. I. (1998). Positional cloning of the zebrafish sauternes gene: A model for congenital sideroblastic anaemia. Nat. Genet., 20: 244-250. 
Chakravarty, S.; Reddy, B. R.; Sudhakar, S. R.; Saxena, S.; Das, T.; Meghah, V.; Brahmendra Swamy, C. V.; Kumar, A. and Idris, M. M. (2013). Chronic unpredictable stress (CUS)-induced anxiety and related mood disorders in a zebrafish model: Altered brain proteome profile implicates mitochondrial dysfunction. PLoS One, 8: e63302.

Chitramuthu, B. P. (2013). Modeling human disease and development in zebrafish. Hum. Genet. Embryol., 3: e108.

Gama Sosa, M. A.; De Gasperi, R. and Elder, G. A. (2012). Modeling human neurodegenerative diseases in transgenic systems. Hum. Genet., 131: 535-563.

Garfield, E. (1996). How can impact factors be improved? BMJ, 313(7054): 411-413.

Gondivkar, S. M.; Sarode, S. C.; Gadbail, A. R.; Gondivkar, R. S.; Chole, R. and Sarode, G. S. (2018). Bibliometric analysis of 100 most cited articles on oral submucous fibrosis. J. Oral Pathol. Med., 47(8): 781-787.

Gore, A. V.; Monzo, K.; Cha, Y. R.; Pan, W. and Weinstein, B. M. (2012). Vascular development in the zebrafish. Cold Spring Harb. Perspect. Med., 2(5): a006684.

Gupta, A.; Kennedy, B.; Meriwether, K. V.; Francis, S. L.; Cardenas-Trowers, O. and Stewart, J. R. (2020). Citation classics: the 100 most cited articles in Urogynecology. Int. Urogynecol. J., 31(2): 249-266.

Guyon, J. R.; Steffen, L. S.; Howell, M. H.; Pusack, T. J.; Lawrence, C. and Kunkel, L. M. (2007). Modeling human muscle disease in zebrafish. Biochim. Biophys. Acta, 1772(2): 205-215.

Hason, M. and Bartůněk, P. (2019). Zebrafish models of cancer-new insights on modeling human cancer in a non-mammalian vertebrate. Genes (Basel), 10(11): 935.

Hayati, F.; Chabib, L.; Silmi Fauzi, I. T.; Awaluddin, R.; Sumayya, Faizah, W. S.; Mohd Nasir, M. H. and Nipun, T. S. (2020). Effects of pegagan (Centella asiatica) ethanolic extract SNEDDS(Self-NanoEmulsifying Drug Delvery Systems) on the development of zebrafish (Danio rerio) embryos. J. Pharm. Bioall. Sci., 12: 457-461.

Howe, K.; Clark, M. D.; Torroja, C. F.; Torrance, J.; Berthelot, C.; Muffato, M.; Collins, J. E.; Humphray, .,; McLaren, K; Matthews, L.; McLaren, S.; Sealy, I.; Caccamo, M.; Churcher, C.; Scott, C.; Barrett, J. C.; Koch, R.; Rauch, G. J.; White, S.; Chow, W.; Kilian, B.; Quintais, L. T.; Guerra-Assunção, J. A.; Zhou, Y.; Gu, Y.; Yen, J.; Vogel, J. H.; Eyre, T.; Redmond, S.; Banerjee, R.; Chi, J.; Fu, B.; Langley, E.; Maguire, S. F.; Laird, G. K.; Lloyd, D.; Kenyon, E.; Donaldson, S.; Sehra, H.; Almeida-King, J.; Loveland, J.; Trevanion, S.; Jones, M.; Quail, M;, Willey, D.; Hunt, A.; Burton, J.; Sims, S.; McLay, K.; Plumb, B.; Davis, J.; Clee, C.; Oliver, K.; Clark, R.; Riddle, C.; Elliot, D.; Threadgold, G.; Harden, G.; Ware, D.; Begum, S.; Mortimore, B.; Kerry, G.; Heath, P.; Phillimore, B.; Tracey, A.; Corby, N.; Dunn, M.; Johnson, C.; Wood, J.; Clark, S.; Pelan, S.; Griffiths, G.; Smith, M.; Glithero, R.; Howden, P.; Barker, N.; Lloyd, C.; Stevens, C.; Harley, J.; Holt, K.; Panagiotidis, G.; Lovell, J.; Beasley, H.; Henderson, C.; Gordon, D.; Auger, K.; Wright, D.; Collins, J.; Raisen, C.; Dyer, L.; Leung, K.; Robertson, L.; Ambridge, K.; Leongamornlert, D.; McGuire, S.; Gilderthorp, R.; Griffiths, C.; Manthravadi, D.; Nichol, S.; Barker, G.; Whitehead, S.; Kay, M.; Brown, J.; Murnane, C.; Gray, E.; Humphries, M.; Sycamore, N.; Barker, D.; Saunders, D.; Wallis, J.; Babbage, A.; Hammond, S.; Mashreghi-Mohammadi, M.; Barr, L.; Martin, S.; Wray, P.; 
Ellington, A.; Matthews, N.; Ellwood, M.; Woodmansey, R.; Clark, G.; Cooper, J.; Tromans, A.; Grafham, D.; Skuce, C.; Pandian, R.; Andrews, R.; Harrison, E.; Kimberley, A.; Garnett, J.; Fosker, N.; Hall, R.; Garner, P.; Kelly, D.; Bird, C.; Palmer, S.; Gehring, I.; Berger, A.; Dooley, C. M.; Ersan-Ürün, Z.; Eser, C.; Geiger, H.; Geisler, M.; Karotki, L.; Kirn, A.; Konantz, J.; Konantz, M.; Oberländer, M.; Rudolph-Geiger, S.; Teucke, M.; Lanz, C.; Raddatz, G.; Osoegawa, K.; Zhu, B.; Rapp, A.; Widaa, S.; Langford, C.; Yang, F.; Schuster, S. C.; Carter, N. P.; Harrow, J.; Ning, Z.; Herrero, J.; Searle, S. M.; Enright, A.; Geisler, R.; Plasterk, R. H.; Lee, C.; Westerfield, M.; de Jong, P. J.; Zon, L. I.; Postlethwait, J. H.; Nüsslein-Volhard, C.; Hubbard, T. J.; Roest Crollius, H.; Rogers, J. and Stemple, D. L. (2013). The zebrafish reference genome sequence and its relationship to the human genome. Nature, 496(7446): 498-503.

Hwang, W.; Fu, Y., Reyon, D.; Maeder, M. L.; Tsai, S. Q.; Sander, J. D.; Peterson, R. T.; Yeh, J-R. J. and Joung, J. K. (2013). Efficient genome editing in zebrafish using a CRISPR-Cas system. Nat. Biotechnol., 31: 227-229.

Jørgensen, L. V. G. (2020). Zebrafish as a model for fish diseases in aquaculture. Pathogens, 9(8): 609.

Kalueff, A. V.; Stewart, A. M. and Gerlai, R. (2014). Zebrafish as an emerging model for studying complex brain disorders. Trends Pharmacol. Sci., 35(2): 63-75.

Kanungo, J.; Cuevas, E.; Ali, S. F. and Paule, M. G. (2014). Zebrafish model in drug safety assessment. Curr. Pharm. Des., 20(34): 5416-5429.

Khan, F. R. and Alhewairini, S. S. (2019). Zebrafish (Danio rerio) as a model organism. In: "Current trends in cancer management." Streba, L., Gheonea, D. I. \& Schenker, M. (Eds.). IntechOpen, UK, pp. 1-16.

Kimmel, C. B.; Ballard, W. W.; Kimmel, S. R.; Ullmann, B. and Schilling, T. F. (1995). Stages of embryonic development of the zebrafish. Dev. Dyn., 203(3): 253310.

Kinth, P.; Mahesh, G. and Panwar, Y. (2013). Mapping of zebrafish research: a global outlook. Zebrafish, 10(4): 510-517.

Lieschke, G. J.; Oates, A. C.; Crowhurst, M. O.; Ward, A. C. and Layton, J. E. (2001). Morphologic and functional characterization of granulocytes and macrophages in embryonic and adult zebrafish. Blood, 98(10): 3087-3096.

Lin, Y. Y. (2012). Muscle diseases in the zebrafish. Neuromuscul. Disord., 22: 673-684.

Liu, S. and Leach, S. D. (2011). Zebrafish models for cancer. Annu. Rev. Pathol., 6: 7193.

Nasevicius, A. and Ekker, S. C. (2000). Effective targeted gene 'knockdown' in zebrafish. Nat. Genet., 26(2): 216-220.

Patil, S. S.; Sarode, S. C.; Sarode, G. S.; Gadbail, A. R.; Gondivkar, S.; Kontham, U. R. and Alqahtani, K. M. (2020). A bibliometric analysis of the 100 most cited articles on early childhood caries. Int. J. Paediatr. Dent., 30(5): 527-535.

Patton, E. E.; Widlund, H. R.; Kutok, J. L.; Kopani, K. R.; Amatruda, J. F.; Murphey, R. D.; Berghmans, S.; Mayhall, E. A.; Traver, D.; Fletcher, C. D.; Aster, J. C.; Granter, S. R.; Look, A. T.; Lee, C.; Fisher, D. E. and Zon, L. I. (2005). BRAF mutations are sufficient to promote nevi formation and cooperate with p53 in the genesis of melanoma. Curr. Biol., 15: 249-254. 
Sarath Babu, N;, Murthy, Ch. L.; Kakara, S.; Sharma, R.; Brahmendra Swamy, C. V. and Idris, M. M. (2016). 1-Methyl-4- phenyl-1, 2,3, 6-tetrahydropyridine induced Parkinson's disease in zebrafish. Proteomics, 16: 1407-1420.

Sehnert, A. J.; Huq, A.; Weinstein, B. M.; Walker, C.; Fishman, M. and Stainier, D. Y. (2002). Cardiac troponin $\mathrm{T}$ is essential in sarcomere assembly and cardiac contractility. Nat. Genet., 31: 106-110.

Tavares, B. and Santos Lopes, S. (2013). The importance of zebrafish in biomedical research. Acta Med. Port., 26(5): 583-592.

Teame, T.; Zhang, Z.; Ran, C.; Zhang, H;, Yang, Y.; Ding, Q.; Xie, M.; Gao, C.; Ye, Y.; Duan, M. and Zhou, Z. (2019). The use of zebrafish (Danio rerio) as biomedical models. Anim. Front., 9(3); 68-77.

Trevarrow, B.; Marks, D. L. and Kimmel, C. B. (1990). Organization of hindbrain segments in the zebrafish embryo. Neuron, 4(5): 669-679.

Trigueiro, N. S. S.; Canedo, A.; Braga, D. L. S.; Luchiari, A. C. and Rocha, T. L. (2020). Zebrafish as an emerging model system in the global south: two decades of research in Brazil. Zebrafish, 17(6): 412-425.

Van der Sar, A. M.; Appelmelk, B. J.; Vandenbroucke-Grauls, C. M. and Bitter, W. (2004). A star with stripes: Zebrafish as an infection model. Trends Microbiol., 12(10): 451-457.

Weinstein, B. (2002). Vascular cell biology in vivo: A new piscine paradigm? Trends Cell Biol., 12(9): 439-445.

Zhao, S.; Huang, J. and Ye, J. (2015). A fresh look at zebrafish from the perspective of cancer research. J. Exp. Clin. Cancer Res., 34: 80. 